\title{
ALL IN THE TRANSLATION: \\ INTERPRETING THE EU CONSTITUTION ${ }^{1}$
}

\author{
Cris Shore
}

\begin{abstract}
This article explores the politics of translation in the context of the European Union and, more specifically, the 2004 EU Constitutional Treaty. The argument is in two parts. The first examines the broader theoretical and conceptual debates in anthropology that have been waged around the idea of 'cultural translation'. Drawing on the work of Asad (1986), Pálsson (1993) and others, I assess the utility of metaphors of domination and appropriation for understanding the politics of translation. I ask, 'does translation necessarily entail asymmetrical relations of power and betrayal, or is it more appropriately conceived as a reciprocal and hermeneutic process of 'empathy' and 'conversation'? I also reflect on some of the problems with the idea of translation as cross-cultural understanding. Using these ideas as an analytical framework, Part Two turns to consider the EU Constitutional Treaty and the contrasting ways that this text was interpreted by European leaders. I suggest that what was presented to the peoples of Europe for ratification was in fact a constitution disguised as a treaty, and one that contained a number of contradictory political agendas. I conclude with two points. First, that where legal texts are concerned, 'translation' is hard to separate from the politics of interpretation. Secondly, that anthropological approaches to translation require a far more expansive definition of what 'cultural translation' actually entails; one that recognizes the complex layers of meaning surrounding this elusive idea and what translation means as institutional practice.
\end{abstract}

INTRODUCTION: THE SEMANTICS AND POLITICS OF TRANSLATION

The official signing of the European Union (EU) constitutional treaty by European Heads of State in June 2004 was hailed a milestone in the history of European integration and a defining moment in the creation of what successive EU 
treaties have proclaimed as the goal of achieving 'ever closer union amongst the peoples of Europe'. In a speech before the signing, European Commission President José Manuel Barroso, declared that the new treaty would give birth to a 'more democratic Union.' The lavish signing ceremony, which took place in the same room where the Treaty of Rome was signed in 1957, was a highly staged and symbolic event:

Classical sculptures and Renaissance painting were complemented by 30,000 Dutch flowers - a dazzling display of reds and yellows. As dreamy music played in the background each leader and foreign minister stepped up in alphabetical country order to sign a giant tome. They shook hands with each other, with a beaming Mr. Berlusconi, and then progressed along a line of dignitaries. Each leader was then presented with a special platinum pen to keep after signing the treaty. ${ }^{3}$

In Germany and France, media analysts and policy professionals had earlier been moved to compare the deliberations of the European Convention which produced this constitutional treaty to those of the famous Philadelphia Convention of 1787 that drafted the United States Constitution. By contrast, these events were portrayed to British voters as a mere 'tidying up exercise' and nothing more significant than a simplification of existing treaties. These widely differing interpretations of the European constitutional debate highlight some of the major discrepancies and cleavages in the way the EU issues are represented and interpreted by political leaders and voters. Yet disputes over the meaning and interpretation of the EU Constitutional Treaty reflect only the tip of the iceberg as far as the problems of translation in the EU are concerned.

This article explores some of the political, epistemological and practical problems of 'translating' legal treaties and technical terminology within the context of the European Union. My aims are twofold. First, to analyse the draft EU Constitutional Treaty in terms of its political and ideological content, and the way this was 'decoded' and interpreted by EU policy makers and political leaders in different member-states. Secondly, and moving beyond this particular example, to reflect more generally on anthropological approaches to the problems of translating within, between and across cultures.

The paper is organized into two parts. Part one explores some of the broader theoretical issues raised in anthropological debates over 'cultural translation' - understood as the process by which alien words, practices and modes of 
thought are rendered meaningful across cultural boundaries. It also examines different understandings of what translation entails in practice. What interest me in particular is the relationship between translation, meaning and institutional power, but I also want to examine some of the various ways in which the idea of 'translation' is itself conceptualized in different settings, and the theoretical and political implications that flow from such conceptions. Much of the anthropological literature to date has focused attention on the language and idioms in which, and through which, translation occurs. Typically, these highlight the way that metaphors of gender, domination and appropriation operate in cultural understandings of what is entailed in the act of translating. ${ }^{4}$ Drawing on the work of Asad (1986), Pállson (1993) and others, I question whether translation necessarily entails asymmetrical relations of power and betrayal, or whether it might more appropriately be construed in terms of a reciprocal and hermeneutic process of empathy and dialogue: a 'conversation' rather than a one-way process of appropriation and subjugation. In the case of legal texts and treaty documents, I contend that translation is invariably about the politics of interpretation and the imposition (or attempted imposition) of meanings that are seldom innocent or neutral. Part of my conclusion, therefore, is that we need to pay much greater attention to the politics of location and to translation as institutional practice, and that this necessarily requires a more expansive and inclusive definition of translation, one that covers the full range of issues and problems that are thrown up by the process of 'rendering ideas and practices meaningful' across cultural divides.

Part Two uses these ideas and insights to explore problems in the translation of treaties, texts and legal terminology within the EU. My particular focus is on debates over the draft EU Constitutional Treaty, which was signed on $29^{\text {th }}$ October 2004 (but subsequently rejected in the French and Dutch referenda of May 2005). While the question most political scientists and EU scholars ask is 'why was the Constitutional Treaty rejected by two member-states that have traditionally been among the most ardent EU supporters?' perhaps the more interesting question is 'how did the EU Constitutional Treaty succeed in getting as far as it did before being checked by the peoples it claimed to speak for'? It is worth noting that both the Spanish and later the Luxembourg electorate overwhelmingly endorsed the treaty in their respective referenda. ${ }^{5} \mathrm{Had}$ it been approved by all EU member-states (a precondition for its passing into law), the Treaty would have given unprecedented powers to the EU's supranational bodies, thereby marking a further step towards the federalist vision of a United States of Europe. However, throughout much of Europe the debate was managed in such a way as to minimize and de-politicize its implications through the use of various discursive techniques and political technologies, 
most of which concerned the interpretation of the Treaty's provisions. In this respect, translating the EU constitutional treaty could be construed as both an exercise in state power and, in other contexts, an act of 'resistance' to EU governance and state power.

PART 1

CULTURAL TRANSLATION: ANTHROPOLOGICAL PERSPECTIVES

It has often been argued that the problem of translation lies at the heart of anthropology (Evans Pritchard 1937; Beidelman 1971; Crick 1976; Tambiah 1990); that the essential task of the anthropologist is to translate the words, ideas, and practices of one culture so that they are meaningful in another. Godfrey Lienhardt (1954), writing over half a century ago captured this idea succinctly when he defined the goal of anthropological enquiry as that of rendering 'alien modes of thought' comprehensible in our own cultural and linguistic terms. The phrase 'cultural translation' has thus often served as a convenient metaphor for explaining to non-anthropologists what anthropologists do (see Hannerz 1993). According to this image, anthropologists are 'semiotic tour guides escorting "alien” readers into rough semiotic space’ (Pálsson (1993:1). However, with the demise of the positivist paradigm in the face of more reflexive and interpretive approaches in anthropology, ${ }^{6}$ this idea has increasingly given way to acknowledgement of the difficulties translating entails, and to the recognition that all translations are necessarily 'interpretations' - and 'second and third order ones to boot' (Geertz 1973:10).

Despite the problems with translation as a conceit, it continues to be used as shorthand for the project of social anthropology. For example, in the introduction to their recent book Cultural Translation, Rubel and Rosman declare (2004:1) that: 'In its broadest sense, translation means cross-cultural understanding. However, whether 'understanding' necessarily follows from translating across cultures is a moot question. For example, what happens in situations of 'bad' translation, where meanings become 'lost in translation', or when the translated text, words or legislation bear little resemblance to the original? Richard Schweder (1996) provides some telling (albeit amusing) examples of this kind of mis-translation, including the infamous story of a Tokyo department store's attempt to reflect (i.e. 'translate') the symbolism of the Christmas season - which resulted in a display of Santa Claus nailed to a cross. Perhaps more worrying examples are found in the context of international law and in the translation of policies, edicts and inter-governmental agreements. For example, depending on one's reading, United Nations Resolution 1441 either gave legal authority for the 'international community' to wage war on Iraq in 
the event of Saddam Hussein's non-compliance, or else required a further UN mandate. In similar vein, the meaning of United Nations Security Council Resolution 242 of November 1967, which called on Israel to withdraw from territories it had occupied following the Six Day War, varies according to whether one reads the French or English translation. As Annabel Black (2000: 255) observes, both English and French texts deployed a studied ambiguity in order to 'avoid specifying how much of the newly occupied territory should be required to be given up by Israel'. Despite the various claims, therefore, about the opportunities for better 'inter-cultural understanding' created by the revolution in modern communications technologies and the 'information super-highway', in an increasingly globalised, mobile, multi-cultural and transnational world, the opportunities for bad translation and mis-interpretation (intentional or unintentional), also appear to be growing.

Among the most significant contributions to anthropological debates about how we might approach the problem of translation is Pállson's edited volume, Beyond Boundaries (1993). A key point that Pállson raises, which I wish to develop here, is that 'translation' is itself a metaphor that can be read in fundamentally different ways, most of which entail relations of power, status and gender. For example, in some contexts a translated text connotes the relative submissiveness or superiority of the translator. As a patriarchal idiom, translation entails 'invasion' 'extraction' and 'bringing home. When we speak of understanding as 'grasping a meaning', it suggests an act of acquisition or possession. It can also be construed in the idioms of sex and violence, as 'an act of appropriative penetration'; that which is 'translated' is represented as 'passive, female prey to be appropriated by the male translator'. This is the language of aggressive masculinity - even rape, with all its connotations of abuse and subjugation. Within anthropology, Pállson suggests that this particular idiom of translation recalls the classic Orientalist ethnography produced during the heyday of Western colonialism (Pállson 1993: 16-17; see also Asad 1973)

By contrast, another supposedly more feminized conception highlights the empathetic aspects of translation and the 'reciprocal or hermeneutic nature of the enterprise.' As Pállson writes, 'if the process of translation is to be described as a love affair, an adequate theory of translation must recognize the role of "empathy" and "seduction"; the author "reaches out" to the translator, altering his or her consciousness just as the translator alters the text' (1992: 17). However, the language of 'seduction' might equally imply 'predation' and 'domination', hence the ambiguity of the translation metaphor and the importance of analyzing it within the specific context of its use. The point here, which is worth emphasizing, is that we can only really grasp the meaning of 
translation and its implications within certain metaphorical frames of reference - those 'metaphors we live by' (Lakoff and Johnson 1984) - and these are invariably culturally specific and politically partial. At the same time, however, we must also be wary not to read too much salience or metaphysics into other people's words or metaphors (Keesing 1985), including our own. In short, the anthropological exploration of cultural translation starts and ends with the analysis of metaphors, semantics and context.

\section{What is 'translation' that anthropology should be wary of it?}

In its literal sense, translation simply means to render or transpose something into another medium. Conventionally, this entails 'the process of reproducing words or text from one language' (the 'source') 'into another' (the 'target'). $^{7}$ Seen in this light, translation is the mapping of meaning between two cultural/linguistic domains; a process of 'de-coding' and 're-coding' words and concepts into the target language. Leaving aside the fact that translating alien cultures is never a simple matter of matching words or sentences in two languages - or that 'good translation' requires a degree of creative license to capture the 'intentio' of the original, but may result in a corruption of that original - the problem with this literal conception is that 'de-coding' and 'mapping' are also metaphors, and ones often associated (particularly in our post-colonial world) with power and conquest. Indeed, historians have often observed how cartography and surveying were central both to the formation of modern nation-states and to the project of colonialism (Hobsbawm 1990; Anderson 1991). This theme is also masterfully portrayed in Brian Friel's (1981) play Translations, which explores the role of English military cartographers in the colonization of rural Ireland, and how the renaming of places was indelibly linked to imperial conquest and expropriation of the land.

This begs the question 'does translation necessarily entail subordination and domination of one kind or another?' Are these the most appropriate idioms for thinking about what is entailed in the process of 'mapping meaning' from one linguistic domain to another? In one sense, these are questions that can only be answered empirically. That said, any translation is likely to be affected by the power relations that exist between source and receptor as in practice, translation takes place on a vertical axis rather than a horizontal one. ${ }^{8}$ This becomes clearer when we take into account the institutional contexts and politics of cultural translation - that is, what translation means as institutionalized practice rather than simply as an abstract philosophical dilemma (Asad 1986:148-9). 
However, one alternative to this dualistic perspective is a conceptualization of translation that stems from the work of Godfrey Lienhardt (1954) and Walter Benjamin (1969). Both Benjamin and Lienhardt (and to a lesser degree also Asad 1986) argued that translation is not simply about rendering words in one language meaningful in another: it is a dialectical process that actively transforms both the culture into which it is translated and source culture. A prime example of this concerns religious 'conversion' and the work of early missionaries in Africa and Asia in translating the Bible into indigenous native languages. This did much more than simply 'de-code' and 're-code' existing meanings: it was a colonial encounter that also served to introduce a whole raft of new concepts and ideas, including Christ our Savior, the saints, heaven, Hell, damnation, salvation and a monotheistic idea of God the Father. But the description of 'heathen' practices of the people converted created concepts and ideas (including 'fetishism', 'taboo' and 'caste') that also found their way back into Western academic discourse (see Taussig 1980; Comoroff and Comoroff 1991).

According to this view, the translation of alien cultures is a two-way, 'dialogic' and mutually transformative process that pushes each language and culture beyond its habitual limits towards a new framework of understanding. Nicholas Dirks (1996) however, challenges this 'translation-as-conversation' model, arguing the politics of translation are inseparable from the politics of location. Writing about the role of Christian missionaries in nineteenth century India, he argues that conversion to Christianity should be seen as;

a more general trope for both translation and appropriation, a sign of the epistemological violence implied by myriad efforts to know, domesticate, name, claim, and ultimately inhabit 'the other'. Conversion is emphatically a one-way street. As such, it is always a relationship of domination, even when the means of domination are much more subtle and even voluntary than in the more general colonial situation (Dirks 1996:121).

What emerges from this brief discussion is that 'translation' is a polysemic concept that has at least four different meanings. For heuristic purposes, I suggest these can be distinguished as follows:

1 First, in its most direct sense, the translation of words from one language to another (i.e. simple linguistic translation, although this is often complicated by the lack of commensurability between semantic fields - a point that Joan Metge illustrates in the case of translating between Maori and English words). ${ }^{9}$ 
2 the translation of concepts and rationalities between cultures (which is de facto, an exercise in cultural comprehension, and which also serves as a trope for anthropology itself);

3 the translation of ideas into practice (which involves action, interpretation and shifting contexts); and finally,

4 translation as institutional practice (which involves institutional context, the politics of location, and the power relations between the different parties involved in the exchange).

What makes the concept of translation even more problematic as an analytical category is that these different meanings frequently overlap or are used interchangeably. The line separating 'translation' from 'interpretation' is often difficult to define with any precision. From an anthropological perspective, therefore, we need to be attentive to the many layers of meaning that inform the act of translation, and the cultural contexts, norms, and forms of power that govern the way translations work. With these considerations in mind, let us turn to examine the problems - epistemological, political and practical - of translating in an EU context.

PART 2

THE EUROPEAN UNION AND THE PROBLEM OF TRANSLATION

The multi-lingual and multicultural character of the EU makes it a particularly interesting site for exploring some of these anthropological debates over cultural translation. Conversely, we might also ask how useful are these anthropological insights into the concept of translation for analyzing the tensions and cleavages within the EU and for understanding how European integration is being 'translated' and experienced in different parts of Europe?

\section{Practical and political issues}

In a very practical sense, translation poses major logistical problems for the EU. As a result of the most recent enlargement on 1 May 2004, the number of official languages in the EU has increased from 11 to 20 . For political reasons, the European Parliament is obliged to offer translation services in all official languages: that means 190 possible combinations (e.g. English-German; Polish-Finnish, Slovene-Lithuanian etc). As one informant put it, 'the EU risks becoming a tower of Babel'. The European commission employs 1,300 translators, who process 1.5 million pages a year. That figure is set to rise to 2.5 
million pages by 2006 - and the staff will be doubled to cope with the output. Translation costs alone are set to rise to 800 million euros per year ( $40 \%$ of administration costs). To help get round these problems, the Parliament proposes to use much more 'relay translation', where a speech is interpreted first into one language, then into another - and perhaps into a fourth. Clearly, the scope for mistakes in this process has become immense. In Brussels, interpreters and translations often compared it to a vast game of 'Chinese whispers'. An anecdote that I heard on several occasions concerned a rather dull technical report in which the phrase 'hydraulic ram' was automatically translated into Greek and other languages as 'watery sheep'. European Commissioner Neil Kinnock recently proposed cutting down on the number of documents translated within the EU by restricting some to the language in which they were originally written. However, this provoked angry responses, particularly from French officials who saw it as a further erosion of the once-dominant position that the French language holds within the EU. Marc Roche, the London correspondent of Le Monde, summed up this view when he described Kinnock's proposals as (sic) 'a perfidious British plot in order to transform the EU into a sort of English speaking area. ${ }^{10}$ As I discovered doing fieldwork in Brussels, the 'equality of languages' is a cardinal principle for the EU. ${ }^{11}$

These technical difficulties, however, are relatively minor when compared with the political problems of translation in the EU, particularly those pertaining to the meaning and interpretation of the vast and growing body of Community law, or what is now termed the 'acquis communautaire'. As Samuel Brittan (2001) observes, this curious phrase - which made its first official appearance in the 1992 Maastricht Treaty - 'exists only in French and denotes what is sometimes translated clumsily as "community patrimony" or "community heritage". ${ }^{12}$ That 'patrimony' includes the whole range of principles, policies, laws, practices and obligations that have been agreed or that have been developed within the European Union (Bainbridge and Teasdale 1995:4). In short the 'acquis' is the collective noun that describes the entire sum of EU legislative acts, regulations and provisions: all those rules and norms that members of the EU must sign up to as a precondition of joining the EU. In 2001 alone this amounted to no less than 80,000 pages in the English version - and even more in the German version. Very few of these 80 , ooo pages would have been discussed or understood, let alone negotiated, by the citizens of Poland, Hungary, Malta or the other recent EU members whose governments agreed to the acquis on their behalf. This adds an interesting twist to our analysis of the politics of translation. It is also significant, perhaps, that the French term 'acquis' is used to refer to "acquired" ground - that is, political or legal areas that have been "communitised", so that they now fall within the "competence" of "the 
Community" rather than that of the member states. ${ }^{13}$ In similar vein, 'communitization' and 'Europeanization' are now frequently used to describe what in EU policy-circles is termed the 'domestication' of national law (Borneman and Fowler 1997; Shore 2000).

\section{Translating the EU Constitutional Treaty: A Treaty or a Constitution?}

If the wholesale incorporation into domestic law of this vast and expanding field of Community law is one important illustration of the politics of treaties and translation in the EU, another key area is the debate over the EU's would-be constitution. On 29 October 2004, after many months of protracted negotiations, back room bargaining and often bad-tempered rows between European Heads of State, the EU constitutional treaty was finally signed in Rome. Although the treaty had yet to be ratified by individual member-states, its formal endorsement represented another milestone in the development of the EU, and a personal triumph for Valery Giscard d'Éstaing, the former French President who chaired the Constitutional Convention that produced the draft.

Here we come to the crux of the matter: how did European policy-makers try to render meaningful, not to mention palatable, the EU's proposed new constitutional order? What did the constitutional treaty say, and how did the peoples of Europe translate it? The remainder of this paper deals with these questions and their implications.

Perhaps the first major issue of 'translation' hinged on the status and definition of the EU 'constitutional treaty' itself, and its alleged hidden political agenda. Generally speaking, a constitution is a document that enshrines national domestic law: it is the solemn act by which a self-recognizing political community, a nation or a people, defines its values and makes provision for the legal rules to which its members will be subject. Constitutions do not fall within the ambit of international law, whose preferred instrument is the treaty. While the EU constitutional treaty was often represented as a constitution, it was in fact not a constitution at all, but a hybrid instrument of exceptional scope. Its provisions not only define fundamental rights (as do most constitutions), they also charge the EU with the goal of pursuing policies that will establish a social market economy where competition is free and undistorted. Yet by eliding the words 'constitution' and 'treaty' (and, in many places in the text, using the word 'EU constitution' to define the treaty) the authors of the treaty were implying that the EU is a unified political community: that, contrary to the whole telos of European integration to date, there exists a 'European nation' or 
'people' whose democratic will can be inscribed in a constitutional text. Ever since the 1940s, supporters of federalism have campaigned for a European constitution, not least because a constitution is the founding instrument of a state, which is the federalist goal. Many critics object to this perceived attempt by the EU to impose a constitution by means of a treaty on grounds of democratic principle. In France, however, this objection was dwarfed by an even greater hostility to the treaty's perceived neo-liberal content. The proclamation of 'a European constitution under the guise of an international treaty', writes Anne-cécile Robert (2004:5), not only 'does violence against democracy', it also 'hides a political agenda connected with the ultra-liberal content of the instrument'.

\section{The Treaty Provisions: Anglo-Saxon neoliberalism or French dirigisme?}

While the Left in France condemned the constitutional treaty as a vehicle for imposing 'Anglo-Saxon' neoliberalism (an ironic charge given that its principal author was a Frenchman and former President of France), detractors on the Right denounced it as a blueprint for European socialism and old-fashioned 'nanny-state' interventionism (or French dirigisme). Curiously, it was neither the political nor economic content of the constitutional treaty that provoked the most heated controversy. This, instead, was sparked by a proposal from several Catholic countries to include reference to Christianity in the preamble to the treaty. ${ }^{14}$ Although that proposal was eventually rejected in favour of a more bland reference to Europe's shared 'cultural, religious and humanist inheritance' (CEC 2004: 3), that debate highlighted some of the deep divisions and historical cleavages within Europe - and the absence of any coherent European identity or common heritage upon which the constitutional principle of 'a people' might be established.

Yet the key legal provisions of the treaty were highly controversial and sweeping. These state, inter alia, that: ${ }^{15}$

1 EU law shall have 'primacy over the laws of the Member States';

2 for the first time, the EU is to be endowed with 'legal personality' (Art. 1-7), which means that, like a state, it can make binding agreements with third countries in all policy areas.

3 the EU's legal personality will over-ride that of its Member-States, who will owe a duty of 'loyalty' to the EU and its goals (see Articles 1-5.2 and 1-15 
4 the symbols of the Union (its flag, anthem, motto, currency and Europe Day) are to be 'constitutionalised' (Article 1-8);

5 the EU Charter of Fundamental Rights is to be legally enshrined (Art. 19), thereby massively increasing the scope for decisions by the European court of Justice to regulate and harmonize national legal systems.

In what is perhaps the most important clause of the entire document, Article 1-12 gives the EU 'competence' to implement its own common foreign and security policy, including the 'progressive framing of a common defense policy'. It also declares that 'the Member-States shall exercise their competence [only if and] to the extent that the Union has not exercised, or has decided to cease exercising, its competence' (Article 1-12.2). In short, 'Union law suppresses national competence to legislate. ${ }^{16}$

In the field of economics, the treaty grants the EU exclusive competence over commercial policy; the internal market (including the movement of persons, goods, services and capital; agricultural policy, fisheries policy and, for all members of the euro-zone, monetary policy. It also enshrines the EU's authority to run the customs union and handle all trade negotiations. Under the principle of 'Shared Competence', Member States are made junior partners in a range of areas, including energy, transport, the environment, public health and consumer protection. It also imposes a guiding role over research, technology and space exploration. The upshot of these combined provisions is very much as Robert (2004) argues: a hybrid document of exceptional power that attempts to impose a constitution (on behalf of the peoples of Europe) through the guise of an international treaty.

British Perspectives: 'tidying up exercise' or 'blueprint for a European superstate?

The contrasting ways that the constitutional treaty was presented to - and interpreted by - the peoples of Europe highlights further issues in the politics of cultural translation. While the treaty was being drafted by a special EU 'Constitutional Convention', a concerted effort was underway, spearheaded by the British government, to convince electors of the Convention's supposed unimportance. Peter Hain, the UK government's Minister for Europe, insisted that it was just a 'tidying up' exercise that would merely reaffirm in more simple terms what the people of Europe had already signed up to years ago. This was also the position of Britain's Foreign Secretary, Jack Straw, who dismissed as 'scaremongering' those who claimed that the treaty would lead to a more 
centralized Europe. In a supercilious repost to Britain's EU critics, he argued that:

The constitution dispatches into oblivion any notion that the EU is a federal superstate. It is the member states that confer competences (powers) on the Union 'to obtain objectives they have in common' (article 1). 'Conferral', meaning that the EU's powers derive from member states, is a fundamental principle, requiring the EU to act 'within the limits of the competences conferred upon it by the member states.' ... overall, it is a good constitution, which sets the right framework for a reformed and effective EU (Straw 2004:40).

It is significant that even the British Foreign Secretary (a lawyer by training) defined the treaty as a 'constitution'. Yet what neither Straw's analysis (nor the constitutional treaty itself) addresses is the problem of 'judicial activism': the way in which the European Court of Justice (ECJ) often uses its rulings to expand the scope of EU competence - which has been one of the major ways that the EU has arrogated to itself powers that were never in the original texts and therefore never formally (or democratically) bequeathed to it by the member states (Neill 1995; Shore 2000: 138). The doctrine of the supremacy of EU law (which was an invention of the European Court of Justice) is an aspect of the EU that has seldom been recognized in any previous EU treaty. Article 1-5a of the 2004 constitutional treaty establishes the supremacy of the ECJ, not only over parliamentary statutes, but also over national constitutions. For the British MEP Daniel Hannan the implications of these measures are clear:

In legal terms, this makes the EU a state. It will henceforth derive it authority, not from any series of international treaties - on the day the constitution enters into force, all existing EU treaties will be dissolved - but from its own founding. ... When the Prime Minister claims that there will be 'no federal state', he is half right. It will be a superstate all right, equipped with every attribute of statehood that international law recognizes: a defined territory, common borders, a citizenry, a legislature, a legal system and supreme court, a constitution, treaty-making powers, a head of state and a defense capability. Article 1-6a also gives it the outward symbols of statehood: a flag, a national anthem ('Ode to Joy'), a motto ('United in Diversity') and a national day (9 May). (Hannan 2004:13).

The British government's outright rejection of the suggestion that the treaty had any major constitutional significance also contrasted markedly with the 
way the treaty was interpreted elsewhere in Europe. In the referendum debates of 2005, for example, the Dutch government warned its electorate that a rejection of the treaty would mean that in the long run, the lights will go out and we will lock our country out of Europe'. The justice minister suggested that Western Europe could even slide into Balkan style wars, while Jan peter Balkenende, the Dutch Prime Minister, stated publicly that a visit to Auschwitz had brought home to him the importance of supporting European integration. ${ }^{17}$ According to this view, the consequences of a 'no' vote thus included economic collapse, war and genocide. High importance was also accorded to the treaty by the German and French governments. In November 2001, the German Chancellor and French President issued a joint statement declaring that the European Convention which produced the treaty was 'a vital step in the historical European integration process' and that the EU should soon become a 'federation of nation states. ${ }^{18}$ Giscard d'Éstaing went further and compared the Convention's deliberations to those of the Philadelphia Convention of 1787, with himself and his colleagues (Jean-Luc Dehaene and Giuliano Amato) as the reincarnation of Madison, Hamilton and Franklin. In Brussels, Giscard was even compared to Socrates for his display of 'authority and wisdom. ${ }^{19}$

Comparisons with the United States are illuminating. Whereas the US Constitution is a short, terse document written in simple and accessible prose, the EU constitution is 283 pages long, is written in turgid legalese (much of which includes detailed technical points about the Common Agricultural and Fisheries Policies), and is virtually unintelligible to all but a small European elite. ${ }^{20}$ Although 'transparency' and 'simplicity' are its stated aims, the opaque and complex language of the text makes it anything but clear. It will be interesting in the future to see exactly how (assuming the treaty is eventually ratified) it will be 'translated' into policy in the EU's twenty-five different member-states - and the legal and linguistic problems such translations will engender. As the articles by Dawson and Goldsmith (this volume) demonstrate, it is hard enough to agree on the meaning and application of a treaty text even when it is written in just two languages, let alone twenty.

Added to this is the further problem of 'Euro-speak'; the EU's curious blend of legal jargon and baffling technical neologisms. To help the public, the EU Convention website created a special dictionary of EU words and phrases. ${ }^{21}$ However, this merely serves to highlight its tortured, complex, legalistic prose. For the letter ' $\mathrm{C}$ ' alone the dictionary include the words 'comitology', 'co-decision procedure', 'community acquis', 'community method', 'principle of communitisation,' 'common position', and 'principle of conferral.' These are techni- 
cal terms whose meanings are contested and obscure even in one culture and language.

In many respects, the political issues surrounding the formation and translation of the constitutional treaty are not new. The 1992 Maastricht Treaty was an equally inscrutable text, even for those legal experts who drafted it. The fear among EU politicians was that the Treaty would not be ratified by the member-states because people would interpret it (correctly) as a massive transfer of sovereignty from elected national Parliaments to non-elected bodies in Brussels, including the European Commission, Council of Ministers and ECJ. To allay people's fears, the drafters of the Maastricht Treaty (or 'Treaty on European Union' to give it its correct title) introduced the term 'subsidiarity' into the text. This had a dramatic effect in helping EU leaders sell the treaty to voters. The reason for this was because 'subsidiarity' was presented as a principle limiting the EU's powers and requiring that decisions should be taken 'as close to the citizen as possible' - or at least wherever this is justified for reasons of necessity or effectiveness. ${ }^{22}$

I was carrying out fieldwork in Brussels at the time and I recall vividly how pleased people in the European Parliament were with this new semantic formula, although few actually understood what it really meant as there was virtually no published literature on the concept. Ken Endo, a student at the Catholic University of Leuven, had recently completed an MA thesis on the topic, so this was rapidly photocopied and disseminated among EU policymakers as though it were an official briefing paper (Endo 1992). In fact, the doctrine of 'subsidiarity' hails from the Catholic Church and was espoused by the Vatican when Mussolini was in power. Far from being a tool of decentralization it is actually an admission that power rest with the higher European authority and that the European courts will decide which of its competences it will delegate. ${ }^{23}$ Even the former President of the European Court of Justice (after retiring from the bench) called it 'a rich and prime example of gobbledygook' and warned that those who perceived it as a constitutional safeguard showed 'great optimism. ${ }^{24}$ And yet this is precisely how it was translated for the peoples of Europe: as a constitutional check on the abuse of power and a bulwark against the very centralization that it helped to advance. 
CONCLUSIONS

'In reality, translation in all its forms is frequently the site of a variety of power plays between the actors involved' (Peter Fawcett 1995: 177).

How then should we make sense of the EU's draft constitutional treaty, and what general lessons can we learn from the way this treaty was articulated, represented and translated by the various interested EU actors? What is clear from the foregoing discussion is that the treaty and its interpretation amounted to far more than a mere 'tidying up' exercise. It was, to use Robert's phrase (2004) an attempted 'legal coup': a 'constitution' in the guise of a treaty.

As noted at the outset, anthropological exploration into the politics of translation often begins with the analysis of the semantics, metaphors and contexts in which translations are conducted. 'Tidying up exercise' is another interesting choice of metaphor: in this case, a comforting domestic idiom chosen to soothe the fears of a skeptical British public. Right wing critics of the EU argued that the constitutional treaty would reduce the role of national parliaments to rubber-stamping, or 'compliance and enforcement agencies for the Union' (Jamieson 2003: 5). Yet left wing critics made a similar argument. Some Labour MPs went even further, describing the EU constitutional treaty as a 'blueprint for a United States of Europe' that actually gives 'much more power to the centre than does the US constitution' (LESC 2003:1). What these narratives show is that the EU constitution opens up enormous scope for legal wrangling over the interpretation of its provisions. And given the nature of 'Eurojargon' (and the increasing prominence of concepts such as 'subsidiarity' 'proportionality', 'additionality' and 'Comitology'), most of this is likely to be conducted in a discourse that is all but incomprehensible to the vast majority of European citizens whose lives are affected by them. The major beneficiaries of this process will therefore be EU policy-makers, legal experts and politicians who owe their status and livelihoods to the European Union.

To conclude, let me return to the broader theme of this paper; namely anthropology and the politics of treaties and translations. In many respects I have expanded the concept of 'cultural translation' to cover a range of subsidiary (albeit related) issues, including the ambiguities inherent in legal texts, discourses and diplomacy, and the dynamics of power in the translation of treaties. In the case of the EU constitutional treaty, as I have argued, these themes are closely connected: 'translating' legal texts is necessarily about the politics of interpretation and the imposition of meanings that are seldom neutral. What 
I have tried to show, however, are some of the contradictory ways in which the constitutional treaty was interpreted and decoded by EU political leaders - and the political agendas that informed those differing translations. What I have not done is explore in any detailed or comparative manner the way the constitutional treaty was received and interpreted by people in the different member-states, or why it was ratified so overwhelmingly in the Spanish and Luxembourg referenda, ${ }^{25}$ but rejected in France and the Netherlands. These questions were beyond the scope of this paper. My focus, instead, had a more limited aim: to explore the EU constitutional treaty through the lens of anthropological debates on translation and, conversely, to reflect on how disputes over the EU constitutional treaty might contribute to anthropological understanding of what translating legal texts entails.

Perhaps the main conclusion I draw from this is the point that Talal Asad made in his 1986 essay: namely that any analysis of cross-cultural translations needs to take into consideration the institutional context and relations of power between the different parties affected in the exchange, including the inequality of languages and what translation means as institutional practice. In this respect, the cultural exchange entailed by the translation of the EU constitutional treaty was quite clearly asymmetrical. What was presented to the peoples of Europe to be ratified (and hence, given democratic legitimacy) was a constitution disguised as a treaty which, had it been endorsed, would have elevated many key areas of domestic policy-making beyond the realm of public debate or national influence, whilst pushing the EU in a more neoliberal direction. From the EU's perspective, the desired outcome was a new constitutional (and federal) order legitimated in the name of the as yet nonexistent 'European people', but one drafted largely over the heads of the vast majority of European citizens. My conclusion therefore diverges from that drawn by Asad and Lienhardt: this was not a case of a two-way exchange or 'conversation' between 'source' and 'target' populations so much as a onedirectional and vertical flow. The translation of the EU constitutional treaty from official Eurojargon into the various national vernacular languages did not 'transform' both cultural systems or push the limits of each language to new heights of mutual comprehension and understanding so much as impose a new and opaque legal terminology, the political effects of which were to disguise the transfer of national competences to the EU. In short, like Nicholas Dirks (1996) argument about Christian 'missionization' in nineteenth century colonial India, 'translation' in this context has to be understood in term of the politics of appropriation, domestication and domination. 
1 I would like to thank my colleagues, Mark Busse, Susanna Trnka, Maureen Molloy, Julie Park and Christine Dureau, for their helpful and constructive comments on an earlier draft of this paper. Thanks also to Susan Wright for her sharp and helpful comments on the structure of the argument.

2 ввс News On-line, http://news.bbc.co.uk/go/pr/fr/-/1/hi/world/europe/3963701. stm (accessed 26/11/04)

3 Tamsin Smith, 29 October 2004. в вс News On-line, http://news.bbc.co.uk/go/ $\mathrm{pr} / \mathrm{fr} /-/ 1 / \mathrm{hi} /$ world/europe/3963701.stm (accessed 26/11/o4)

4 For a lively analysis of the use of container and possession metaphors - particularly the metaphor of 'understanding as grasping', see Dawson's essay, this Issue.

5 In the case of Spain, public enthusiasm for the EU derives largely from the fact that the EU is closely associated with the end of Francoist isolation and what many Spaniards perceive as Spain's return to the family of European democracies. Large flows of EU money in the form of regional and agricultural subsidies have also played a role. It is perhaps significant, therefore, that while opinion polls in February 2005 showed that $88 \%$ of Spaniards said they knew northing or 'very little' about the European Constitutional Treaty, 56\% also pronounced themselves in favour of it (Source: The Economist 12 February 2005).

6 In philosophy, this idea also came under attack in the work of W. V. Quine and others on the indeterminacy of translation and the arbitrariness of words and their meanings.

7 Oxford Dictionary of English On-line: http://www.oxfordreference.com.ezproxy. Date accessed 30/08/2005.

8 Lefevere and Bassnett 1990: 1, cited in Pálsson 1993: 15.

9 See Joan Metge's essay in this collection.

10 Cited in ввс News online, Tuesday 14 August 2001, 14.23 Gмт. Source: http// newsvote.bbc.co.uk/mpapps/pagetools/print/news.bbc.co.uk/1/hi/world/Europe (visited 16/10/04).

11 This is particular the case with the European Parliament. 
12 Samuel Brittan 2001 'The greatest perversity of the European Union', Financial Times 26/04/01:14.

13 Source: Euro-Know How 2005 'Europe - a concise encyclopaedia', http://www. euro-know.org/dictionary/a.html (accessed 30/o8/2005).

14 Seven member-states, led by Poland, Italy, Lithuania, Malta, Portugal, Slovakia and the Czech Republic - and with strong backing from the Pope - sent a letter to the Irish Presidency demanding that there should be a reference to Christianity in the Constitution. Other member states (notably France) vigorously opposed having any reference to religion in the constitution.

15 Articles 1-5 - 1-15 of the EU Constitutional Treaty (CEC 2004)

16 This is also the interpretation of Danish MEP Jens-Peter Bonde 'The EU Constitutions - reader friendly edition', 23-06-2004. Available at: http://www.bonde. $\mathrm{com} /$ ? sid=531 (accessed 30/11/04).

17 The Economist 2005 'Charlemagne', 21 May Available at http://global.factiva.com. ezproxy.auckland.ac.nz/en/arch/print_results.asp (accessed 18/10/05).

18 Cited in Pinto-Duschinsky 2003:3

19 Among the many other accolades, Giscard was also hailed as 'the midwife to Europe', see Parker, George and Dombey, Daniel 2003, 'More than we could have hoped for', Financial Times, 19/06/o4

20 The first sentence of the treaty alone runs to over 400 words.

21 The EU's dictionary of what it calls 'Eurojargon' can be found on the EU's main 'europa' website: http://europa.eu.int/abc/eurojargon/index_en.htm

22 The subsidiarity principle states that: 'In areas which do not fall within its exclusive competence, the Community shall take action, in accordance with the principle of subsidiarity, only if and insofar as the objectives of the proposed action cannot be sufficiently achieved by the Member States and can therefore, by reason of scale or effects of the proposed action, be better achieved by the Community' (Article 3b EEC; also cited in Bainbridge 1998:465).

23 As Michael Pinto-Duschinsky (2003:14) argues, '[I]t is open to argument that "subsidiarity" may actually serve to provide cover for the progressive assump- 
tion of power by the EU', not least because under the doctrine of subsidiarity, the question of who decides whether a decisions are to be taken in Brussels, London or at regional level is removed in most cases from elected national legislators. For a more detailed analysis, see Schilling 1995.

24 Lord Mackenzie Stuart raised these objections in an article for the London Times (15 June 1992); for a more detailed explication of his case, see his second article, 'A formula for failure', The Times 11 December 1992.

25 In the Spanish referendum, held on 20 February 2005 , a majority of $76.73 \%$ of voters backed the Constitutional Treaty while $17.24 \%$ voted against it and $6.03 \%$ returned a blank voting paper. Voter turnout was $42.32 \%$. Luxembourg's referendum took place on 10 July 2005 , with $56.52 \%$ for the treaty and $43.48 \%$ against. For a useful analysis of the main national issues concerning the EU constitutional treaty in those member-states that had opted to hold referenda, see Daniel Keohane 2004.

\section{REFERENCES}

Asad, Talal 1986 'The Concept of Cultural Translation' in J. Clifford and E. Marcus (eds), Writing Culture, University of California Press.

Anderson, Benedict 1983 Imagined Communities: Reflections on the Origin and Spread of Nationalism, London: Verso.

Bainbridge, Timothy and Teasdale, Anthony 1995 Penguin Companion to European Union, Harmondsworth: Penguin.

Beidelman, Thomas (ed.) 1971 The Translation of Culture: Essays to E. E. EvansPritchard, London, Tavistock.

Bell, J. 2004 'O say, can you see: Free expression by the light of fiery crosses', Civil Rights-Civil Liberties Law Review 39 (2): 335-389.

Benjamin, Walter 1969 [1923] Illuminations, New York: Schocken.

Bercow, John 2003 'Subsidiarity and the Illusion of Democratic Control', EU Constitutional Briefing Paper No. 3, London: Bruges Group.

Black, Annabel 2001 'Ambiguity and verbal disguise within diplomatic culture', in J. Hendry and C. Watson (eds) An Anthropology of Indirect Communication, 
London: Routledge: 255-70.

Borger, Julian, 2004 “'Dirty” war for profit evades reach of law', Guardian Weekly, May 6-12 2004: 6.

Borneman, John and Nick Fowler 1997 'Europeanization' Annual Review of Anthropology, 26: 487-514.

Commission of the European Union (CEC) 2004, Treaty Establishing a Constitution for Europe, (CIG 87/2/O4 REV 2), Brussels, 29 October. http://www.europa.eu.int/constitution/download/part_I_EN.pdf [Accessed 30/11/2004].

Comoroff, Jean .and Comoroff, John 1991 Of Revelation and Revolution: Christianity, Colonialism and Consciousness in South Africa, Chicago: Chicago University Press.

Crick, Malcolm 1976 Explorations in Language and Meaning: Towards a Semantic Anthropology, London: Malaby Press.

Dirks, Nicholas 1996 'The Conversion of Caste: Location, Translation and Appropriation', in P. Van der Veer (ed.) Conversion to Modernities: The Globalization of Christianity, New York/London: Routledge: 115-136.

Endo, Ken 1992 Principle of Subsidiarity: Its Origin, Historical Development and its Role in the European Community, MA Dissertation submitted to the Catholic University of Leuven, Leuven, (Belgium) June.

Evans Pritchard, E. E. [1937] 1950 Witchcraft, Oracle and Magic among the Azande, Oxford: Clarendon Press.

Fawcett, Peter 1995 'Translation and Power Play', The Translator, 1 (2): 177-192

Friel, Brian 1981 Translations, London: Faber and Faber.

Geertz, Clifford 1973 The Interpretation of Culture, New York: Basic Books.

Hannan, Daniel, 2004 'The way ahead for Europe' The Spectator, 26 June: 12-14.

Hannerz, Ulf 1993 'Mediations in the Global Ecumene', in Pálsson G. (ed.) Beyond Boundaries, Oxford: Berg: 41-57. 
Hobsbawm, Eric 1990 Nations and Nationalism since 1789, Cambridge: Cambridge University Press.

Jamieson, Bill 2003 A Constitution to Destroy Europe, London: Bruges Group - EU Constitution Briefing Paper o2 (also available at http://www.brugesgroup.com).

Keesing, Roger 1985 Conventional metaphors and anthropological metaphysics: the problematic of cultural translation, Journal of anthropological research 41, (2):201-217.

Keohane, Daniel 2004 'Referendum Season in Europe. A Guide to the Referenda on the EU Constitutional Treaty - a briefing note', Centre for European Reform (4 February). Available at: http://www.cer.org.uk/eu/

Kooiman, J. (ed.) 1993 Modern Governance: New Government-Society Interactions, London: Sage.

Labour Euro-Safeguards Committee (LESC) 2003 'More Questions and Answers on the EU Constitutional Convention', LESC Bulletin, London: May 2003.

Lackoff, George and Johnson, Mark 1980 Metaphors We Live By, Chicago: University of Chicago Press.

Leinhardt, Godfrey 1954 'Modes of Thought' in E.E. Evans-Pritchard The Institutions of Primitive Society, Oxford: Blackwell: 95-107.

Neill, Patrick 1995 The European Court of Justice: A case study in judicial activism, (unpublished manuscript, London, 13 January).

Pálsson, Gísli 1993, 'Introduction: beyond boundaries' in G. Palsson (ed.) Beyond Boundaries. Understanding, Translation and Anthropological Discourse Oxford: Berg.

Pinto-Duschinsky, Michael 2003 'All in the Translation: What the proposed European Constitution means for Britain', Times Literary Supplement, 13 June 2003:3-5.

Robert, Anne-cécile 2004 'EU: a legal coup', Le Monde Diplomatique, (English Language Edition) November: 5 . 
Rose, Nikolas 1999 Powers of Freedom, Cambridge: Cambridge University Press

Rubel, Paula and Rosman, Abraham 2003 'Introduction: Translation and Anthropology', in P. Rubel and A. Rosman (eds) Translating Cultures: Perspectives on Translation and Anthropology, Oxford: Berg.

Schilling, Theodor, 1995 Subsidiarity as a Rule and a Principle, or: Taking Subsidiarity Seriously Jean Monnet for International and Regional Economic Law and Justice, NYu School of Law, (Working Papers 10/95), available at http://www.jeanmonnetprogram.org/papers/95/9510ind.html.

Schweder, Richard 1996 'Santa Claus on the Cross', in J. Anderson (ed.) The Fontana Postmodernism Reader, London: Fontana: 68-74.

Shore, Cris, and Wright, Susan 1997 'Policy: A New Field of Anthropology' in C. Shore and S. Wright (eds) Anthropology of Policy, New York/London: Routledge: 3-39.

Shore, Cris 2000 Building Europe: The Cultural Politics of European Integration, New York/London: Routledge.

Shuttleworth, Mark and Cowie, Moira 1997 Dictionary of Translation Studies, Manchester: St. Jerome Publishing.

Straw, Jack 2004 'Europe', The Economist Vol. 372, No. 8383:40.

Szamuely, Helen 2004 'But Does God Support the EU Constitution?' The Bruges Group Comment and Analysis Paper, www.burgesgroup.com/euconstitution (accessed 3/6/04).

Tambiah, Stanley 1990 Magic, Science, Religion, and the Scope of Rationality, Cambridge: Cambridge University Press.

Taussig, Michael 1980 The Devil and Commodity Fetishism in South America, Chapell Hill: University of North Carolina Press. 